\title{
THE IMPACT OF DIFFERENT STOCKING DENESITIES AND DIETARY PROTEIN LEVELS ON THE PERFORMANCE OF AFRICAN CATFISH (Clarias gariepinus) FINGERLINGS
}

\author{
Fawzy I. Magouz ${ }^{1}$; Malik M. Khalafalla ${ }^{2}$,Eman M. Moustafa ${ }^{3 *}$ Amir S. Sadek ${ }^{1}$
}

${ }^{1}$ Department of Animal Production, Faculty of Agriculture, Kafrelsheikh University, ${ }^{2}$ Department of Aquaculture, Faculty of Aquatic and Fisheries Sciences, Kafrelsheikh University, ${ }^{3}$ Department of Fish Diseases and Management, Faculty of Veterinary Medicine, Kafrelsheikh University, Egypt

*Corresponding author, E-mail: emantarek2002@yahoo.com

\begin{abstract}
The current experiment was randomly designed as a $3 \times 2$ factorial design to investigate the effects of two fixed factor (stocking density \& dietary protein level) on growth performance, feed utilization, survival rate and physiological response of African catfish (Clarias gariepinus). Fishes were allotted in 18 concrete $\left(8 \times 3 \times 0.5 \mathrm{~m}^{3} ; \mathrm{L} \times \mathrm{W} \times \mathrm{H}\right)$ tanks at three different stocking density 30,20 and 10 catfish fingerlings / $\mathrm{m} 3$ and fed on two different protein diets (25 and $30 \%$ ). Each treatment was applied in three replicates. Fishes were fed $2.5 \%$ of biomass body weight twice/day. Results showed that growth performance, feed utilization, survival rate and hematological parameters were significantly improved with increased dietary protein level with low stocking density. The sixth treatment (high protein level 30\% and lowest stocking density; $10 \mathrm{fish} / \mathrm{m}^{3}$ ) exhibited the highest growth performance with no mortalities. Based on the results of the current study, it could be recommended to use protein level diet of $30 \%$ or more and stocking density of 10 catfish fingerlings/ $\mathrm{m}^{3}$ to obtain high productivity in a short time with consequent decreased cost.
\end{abstract}

Key words: African catfish; Clarias gariepinus; dietary protein; growth parameters; Stocking density

\section{Introduction}

Fish is one of the most important alternative sources of dietary protein required to meet the increased human population demand in Egypt together with deceased other sources of animal protein (1). Aquaculture is considered a main key for bridging the national fish demand-supply gap (2). Increasing aquaculture production is clearly needed to meet this demand in the third millennium, because capture fisheries is

Received: January 2019

Accepted for publication: February 2019 showing precipitous decline due to habitat destruction, over fishing and pollution (3).

The utmost aquaculture goal is the production of high quality, high quantity, and low cost fish in short possible time. This can be achieved by careful species selection, good water quality, appropriate feeding and suitable stocking density (4).That is why it is important to determine the best carrying capacity of an aquatic environment in which we can keep certain numbers of fish in a given volume of the culture media resulting in the highest fish yield without negative 
effect on growth rate depending mainly on the amount and the quality of available food (5)

African catfish (Clarias gariepinus) is an endemic popular aquaculture species largely distributed in most African and Asian countries (610). It is widely cultured in freshwater ponds because of its high growth rate with excellent quality meat, ability to accept a wide variety of feed, resistance to diseases, easiness in reproduction and its ability to tolerate adverse environmental conditions, and high stocking densities under poly-culture conditions (7, 10-13).

The most critical aspect of aquaculture is to rear the early life stages of fish (fry and fingerlings) $(14,15)$ because fish at these stages are very sensitive to the different factors or determinants of production. Inadequate stocking densities and poor quality feed have a major role in poor growth and low survival rate of fry and/or fingerling stages resulting consequently in lower production

African catfish are carnivorous as well as predatory; having good special appetite for high protein diet. Therefore, dietary protein levels must be adjusted to meet their requirements. Moreover, stocking densities should be optimized to ensure that the available food is utilized more efficiently with maximum space utilization (16).

The present work was conducted to evaluate the effect of two different levels of dietary protein together with varying degrees of stocking density on the growth parameters, feed efficiency, nutrient utilization, hematological parameters and survival rate of African catfish fingerlings in concrete tanks.

\section{Materials and methods}

The present work was carried out in one of the commercial fish farms located at Kafr ElSheikh Governorate, Egypt, in co-operation with the Animal Production Department, Faculty of Agriculture, Kafrelsheikh University, during the year 2017.

\section{Fish}

A number of 4320 African catfish fingerlings (Clarias gariepinus) with an average initial weight of $(50 \pm 2 \mathrm{~g})$ were obtained from a private hatchery in Kafr El-Sheikh governorate. The fish were treated with potassium permanganate solution (3ppm) and acclimatized on the new environment (experimental conditions) for two weeks before the beginning of the experiment in concrete tanks. During the adaptation period, the fish were supplied with natural feeding (trash fish).

\section{Experimental design}

The experiment was randomly designed in a $3 \times 2$ factorial design. Three stocking densities were used with two levels of dietary protein. Thus, a total of six treatments run in triplicate were allotted into18tanks. Treatments (1-3) comprised of fingerlings fed with $25 \% \mathrm{CP}$ and stocked at 30, 20, 10 fingerlings $/ \mathrm{m}^{3}$, respectively. However, Treatments (4-6) comprised of fingerlings fed with $30 \% \mathrm{CP}$ and stocked at 30 , 20, 10 fingerlings $/ \mathrm{m}^{3}$, respectively.

Catfish fingerlings $(50 \pm 2 \mathrm{~g})$ were randomly stocked in 18 concrete tanks each was $\left(8 \times 3 \times 0.5 \mathrm{~m}^{3}\right)$ capacity. All tanks were supplied with drainage water from drain El-Mohet through inlet PVC pipes ( 2 inch in diameter). Water outlet was found to be at a rate of 15 liter per minute. The fish were fed at a level of $2.5 \%$ of live body weight for about 90 days (experimental period).

\section{Diets}

Two tested diets containing 25 and $30 \%$ protein levels were formulated from the local ingredients including fish meal, soybean meal, yellow corn, wheat bran, rice bran, wheat middling, sun flower oils, vitamins and minerals mixture, and Di-calcium phosphate to obtain control diet. The premix was added to all the experimental diets. The composition of the experimental diets was showed in table $(1, \mathrm{~A})$. The diets were prepared by thoroughly mixing the dry ingredients at first then mixed with oil. The diets were analyzed at The Central Laboratory of Food \& Feed (CLFF), Agricultural Research Center, Ministry of Agriculture. Chemical composition and calculated gross energy of different experimental diets are presented in Table $(1, \mathrm{~B})$. First experimental diet (Diet1) consist of $25 \%$ crude protein and $408.14 \mathrm{kcal} / 100 \mathrm{~g}$ 
gross energy and the second experimental diet (Diet 2 ) consist of $30 \%$ crude protein and 420.73 $\mathrm{kcal} / 100 \mathrm{~g}$ gross energy.

\section{Feeding regime}

Catfish were fed natural feeding for two weeks during the acclimatization period in the experimental tanks. After the two weeks of acclimatization, the catfish were fed the experimental diets at $2.5 \%$ from the total biomass daily for 90 days, and were applied twice a day (at 10:00 am \& 14:00 pm). The feed amount was adjusted every seven days according to the new weight of the fish.

\section{Proximate chemical analysis}

Samples of the experimental diets as well as the experimental fish at the start and at the end of the experiments were obtained and then force dried, milled and deep frozen until determination the chemical analysis according to the methods described by (17).

\section{Water quality management}

Water quality parameters, such as temperature, dissolved oxygen, $\mathrm{pH}$, alkalinity, hardness, ammonia, nitrate, nitrite and water salinity were estimated throughout the experiment. Water temperature was measured using thermometer. Oxygen level was measured daily at 8 o'clock by using oxygen meter (Model FE 247, EDT Instruments LTD. Dover Kent, UK). The $\mathrm{pH}$ was monitored using $\mathrm{pH}$ meter (Model Digi-sense, Cole-Parmer Instruments Co. Vernon Hills, IL. USA, Figure 1). Alkalinity was determined using test kit (Model WATDR. Code 4491-DR, LaMotte CO. Chestertown, Maryland, USA). Hardness was determined using test kit (Model HA-DT Cat. 20636-00, Hach Co. Loveland, Colorado, USA). Ammonia-N was estimated using test kit (Model NI, Cat. No. 22669-00, Hach Co.). Nitrite and nitrate were measured using test kits (Model NI-16 Cat. No. 20596-00 and Model NI-14 Cat.No. 14161-00, Hach Co., respectively). Determinations were carried out weekly according to APHA (18).

Determination of fish growth parameters

Growth and feed utilization were assessed by calculating average weight gain, average daily gain, specific growth rate, protein efficiency ratio, feed intake, feed conversion ratio, feed efficiency and survival rate:

Live body weight (LBW) was assessed in $\mathrm{g}$ for each individual group of each experimental treatment and recorded every 2 weeks (14 days).Total weight gain $(\mathrm{TWG})(\mathrm{g} / \mathrm{fish})=$ final body weight - initial body weight (19). Specific growth rate $(\mathrm{SGR} \% /$ day $)=[\mathrm{Ln}$ final body weight- Ln initial body weight] $\times 100$ /experimental period(d) (20). Average daily gain $(\mathrm{ADG})=(\mathrm{W} 2-\mathrm{W} 1) / \mathrm{t}$; where: $\mathrm{W} 2$ is the final weight, $\mathrm{W} 1$ initial weight and $\mathrm{t}$ is the time in days. Feed conversion ratio $(\mathrm{FCR})=$ feed intake $(\mathrm{g}) /$ weight gain $(\mathrm{g})(21)$. Protein efficiency ratio $(\mathrm{PER})=$ weight gain $(\mathrm{g}) /$ protein intake $(\mathrm{g})$. Protein productive value $(\mathrm{PPV} \%)=100 \times($ protein gain $(\mathrm{g}) /$ protein intake $(\mathrm{g})$ ). Survival rate (SR $\%)=$ total number of fish at the end of the experiment $\times 100 /$ total number of fish at the start of the experiment.

\section{Hematological investigations}

At the end of the experiment, fish in each group (3-4 fish) were weighed and blood samples were taken randomly from the caudal vein for blood analysis and differential leukocyte count. Anti-coagulated blood samples were prepared immediately for counting red and white blood cells, etc. Red blood cells count $\left(\mathrm{RBCs} \times 10^{6} / \mathrm{mm}\right)$ and white blood cells count (WBCs $\times 10^{3} / \mathrm{mm}$ ): were determined according to the method described by Stoskopf, (22). Hemoglobin concentration $(\mathrm{Hbgm} / \mathrm{dl})$ was estimated according to the method of Zinkl (23) and Packed cell volume (PCV\%): was estimated by the microhaematocrite method described by Decie\& Lewis (24).

\section{Statistical Analysis}

The obtained numerical data were statistically analyzed using SPSS (25) for two-way analysis of variance at $5 \%$ level of significance. When Ftest was significant, least significant difference was calculated according to Duncan (26).

\section{Results and discussion}

Growth is the principal key of energy loss and/or gains in the aquatic environment; which 
can be measured mainly by determination of the weight gain. Stocking density is a main factor significantly affecting the growth, feed utilization (FCR) and survival rate (SR) of the catfish fingerlings. High stocking densities act as stressors, fish aggregate for the same amount of feed and some of them cann't eat resulting in growth retardation (27) and/or decrease of feed utilization (28). Moreover, in high stocking densities, there is increased oxygen demand needed either for respiration or metabolism. Therefore, it is very important to adjust the stocking density with the carrying capacity of the aquaculture system.

\section{Growth performance and survival rate}

As shown in table 2, catfish fed on $30 \%$ protein level diet showed better final weights compared to those fed $\mathrm{g}$ on $25 \%$ protein level diet at the different stocking densities. The final weight was significantly increased with increased protein in diet $(\mathrm{P} \leq 0.05)$. The final weight of Treatment 1 (T1) was the lowest weight $(214.3 \pm 10.12)$ compared with the other treatments. While, final weight of treatment six (T6) was the highest weight $(284.00 \pm 14.32)$ $(\mathrm{P} \leq 0.05)$ compared with the other treatments. The average weight gain (AWG) was improved especially in groups fed on high protein level. While, the first treatment (T1) showed the lowest AWG (164.30 \pm 8.24$)$ compared with other treatments. Similarly, average daily weight gain (ADG) of treatments (4-6) feeding on 30\% protein was better than treatments $(1-3)$ feeing on $25 \%$ protein diet in all variant stocking densities; with the highest value recorded in treatment $6(2.60 \pm 0.63)$ and the lowest value in treatment $1(1.83 \pm 0.42)$. Besides, the highest SGR $(1.71 \pm 0.41)$ was observed in treatment 6 . The results are similar to those reported by some authors (29-33), where they reported that increased protein concentration in the diet has a positive correlation with the final weight gain expressed as AWG, ADG and SGR.

On the other hand, results of the present study showed that the decreasing stocking density, the increased final weight. Decreased stocking density significantly affected the final weight gain, the highest stocking density in treatment $1\left(30 \mathrm{fish} / \mathrm{m}^{3}\right)(214.30 \pm 10.12)$ gave the worst final body weight compared with treatment $3\left(10 \mathrm{fish} / \mathrm{m}^{3}\right)(256.30 \pm 12.54)$, although both treatments feed on the same protein level diet $25 \%$. These results also could be observed in fingerlings fed on $30 \%$ protein level diet, where treatment $6\left(10 \mathrm{fish} / \mathrm{m}^{3}\right)$ showed the best result of all growth parameters compared with other groups. This means that decreasing the stocking density gave a positive effect $(\mathrm{P} \leq$ 0.05 ) of final weight gain. These results agreed with many authors (34-38), where they found that increased stocking density resulted in less AWG, ADG and SGR.

Survival rate of the experimental fish was recorded. It was $100 \%$ in treatments $2,3,5$ and 6 (low stocking density), but treatment 1 and 4 (highest stocking density) lost some fingerlings in the first days of experiment. This may be attributed to increased oxygen demand in high stocking treatments which may result in fish may succumb to suffocation. Survival rate increases with increased dietary protein level, this may be attributed to that low protein diets might have not met the nutrition requirements of catfish fingerlings and thereby leading to nutrient-deficient related mortalities $(39,40)$.

\section{Water quality parameters}

Water quality parameters of the experimental ponds were insignificantly affected by different treatments during the experimental period (90 days). As summarized in table 3, all water parameters for all experimental ponds showed that, dissolved oxygen not least $4 \mathrm{mg} /$ litter, toxic ammonia (NH3) no more than 0.6 $\mathrm{mg} /$ litter, $\mathrm{pH}$ values between 8.2 and 8.5 degree, nitrate (NO2) no more than $0.2 \mathrm{mg} /$ litter, alkalinity 320 , hardiness 150 , salinity between 2000 and 4000 ppm (source of water was brackish water) and temperature about $27^{\circ} \mathrm{C}$. Water quality parameters observed in the current study were within the normal ranges required for normal growth of African catfish (9, 33, 39, 41-45); consequently any changes in the growth parameters may be attributed either protein level diet and/or stocking density. 


\section{Feed intake and nutrient utilization}

As shown in table 4; holding all factors including the different stocking density of the present study, results showed that dietary protein has a marked influence on feed utilization. Results showed that increasing the level of protein in the diet increased significantly $(\mathrm{P} \leq 0.05)$ feed conversion ratio of fish. Diet $30 \%$ protein gave the best results $(\mathrm{P} \leq 0.05)$ of feed conversion ratio compared with diet $25 \%$ protein with different stocking densities; and the sixth treatment $(1.00 \pm 0.09)$ gave the best feed conversion ratio (FCR) compared with the third treatment $(1.13 \pm 0.11)$ ( same of stocking density)while the first treatment $(1.40 \pm 0.24)$ was the worst treatment compare with other treatments. Besides, increasing protein level in the diets affected significantly $(\mathrm{P} \leq 0.05)$ protein efficient ratio (PER) of fish. The same trend was observed with protein productive value (PPV); these results of feed utilization may be due to the impact of different protein levels together with different stocking densities. Protein efficiency ratio (PER) and protein productive value (PPV) were better generally with low stocking densities and high protein level diets. These results are in full agreement with some authors (35, 46-50).

Body composition of African catfish as affected by the experimental diets

Data concerning body composition responses of African catfish presented in table 5 revealed that the dry matter, crude protein, ether extract contents were increased by the time from the start to the end of experimental period (90) day, but the opposite was true for the ash percentage. Increasing protein level in the diet affected crude protein of body composition significantly $(\mathrm{P} \leq 0.05)$. Fingerlings in treatment 1 $(25 \%$ protein) had low crude protein $(66.92 \pm 5.36)(\mathrm{P} \geq 0.05)$ as compared with the other treatments, while the sixth treatment (30\% protein) $(67.39 \pm 5.47)$ was the best in crude protein $(\mathrm{CP})$ content $(\mathrm{P} \geq 0.05)$ compared with other treatments. However, dry matter (DM) in was low in treatment $1(28.78 \pm 1.58)$ as compared with the other treatments, while sixth treatment $(29.21 \pm 1.75)$ was the best treatment compared with the different treatments. Results also revealed that increasing level of protein in diet affected positively $(\mathrm{P} \leq 0.05)$ ether extract (EE) and gross energy (GE) of fish body.

\section{Hematological investigation}

As summarized in table (6), there was a significant increase in RBCs, Hb, PCV and WBCs in all treatments; the sixth treatment (30\% protein and low stocking density) showed the best hematological parameters and treatment $1(25 \%$ protein and high stocking density) showed the worst hematological results. These results suggest that the physiological response of catfish fingerlings is improved when fed high protein level diet together with existing low stocking density.

In the present study, Growth depression observed in higher stocking densities groups may be attributed to reduced amount of adequate oxygen, followed by slowed down metabolism resulting in lower growth than in lower stocking density $(27,51)$. The decreased FCR at high stocking density (30 fish $/ \mathrm{m}^{3}$ ) may confirm that high stocking density reduced feed utilization efficiency. Due to competition for feed, there is low feed intake and consequently lower energy levels necessary for metabolism which is responsible to convert nutrients into fish flesh.

Growth depression observed in lower protein level diets has been observed in various fish species under captivity; this might be due to reduction in the available energy for growth (52, 53 ). Fish usually obtain energy from chemical breakdown of proteins than large animals that is why high protein is highly important in fish diet (54). Lowest growth in $25 \%$ protein level diet may be due to that most of protein was used for maintain life but unavailable for growth; however $30 \%$ protein level diet resulted in higher growth rate and better feed utilization in catfish fingerlings.

High focusing to body protein is of a great importance to meet the dietary requirements for tissue building, metabolism and repair; as a result of poor growth and poor feed utilization in fish group fed low protein level in the current study (55).This means the fingerlings survived in low stocking density and fed on $30 \%$ protein 
level diet could use dietary protein more efficiently than fish survived in higher stocking densities and fed on $25 \%$ protein level diet.

Table 1A: Composition of the experimental diets

\begin{tabular}{lcc}
\hline \multicolumn{1}{c}{ Raw Ingredients } & \multicolumn{2}{c}{ Composition $(\%)$ experimental diets } \\
Diet $2(30 \%$ Protein $)$
\end{tabular}

(1)Premix Composition:- Each $3 \mathrm{~kg}$ contains, Vit A (1200000 i.u.), Vit D (300000 i.u.), Vit E (700 mg,) Vit K3 (500 mg,) Vit B1 (500 mg), Vit B2 200mg, Vit B6 (600mg), Vit B12 (3mg), Vit C 450mg, Niacin 3000mg, Methionine3000mg, Cholin chloride 10000mg, Folic acid 300mg, Biotin 6mg, Panthonic acid 670mg, Magnesiam salphate $3000 \mathrm{mg}$, Copper sulphate $3000 \mathrm{mg}$, Iron sulphate $10000 \mathrm{mg}$, Zinc sulphate, $1800 \mathrm{mg}$, Cobalt sulphate $300 \mathrm{mg}$, Carrier upto $3000 \mathrm{mg}$.

Table 1B: Proximate analysis of the experimental diets

\begin{tabular}{lcc}
\hline Composition $(\%)$ & Diet $1(25 \% \mathrm{CP})$ & Diet $2(30 \% \mathrm{CP})$ \\
\hline Dry matter & 90.30 & 90.90 \\
Organic matter & 78.30 & 80.50 \\
Crude Protein & 25.45 & 30.40 \\
Ether extract & 5.40 & 5.00 \\
Crude Fiber & 6.60 & 6.40 \\
Ash & 12.00 & 10.40 \\
Nitrogen free extract & 50.55 & 47.80 \\
Calculated energy value: & & \\
$*$ GE $(\mathrm{kcal} / 100 \mathrm{~g})$ & 408.14 & 420.73 \\
$* *$ DE $(\mathrm{kcal} / \mathrm{g})$ & 306.11 & 315.55 \\
\hline
\end{tabular}

${ }^{*}$ GE (gross energy) was calculated according to NRC (1993) by factors of 5.65, 9.45 and $4.22 \mathrm{kcal}$ per gram of protein, Lipid and carbohydrate, respectively. ${ }^{* * *} \mathrm{DE}$ (digestible energy) was calculated by applying the coefficient of 0.75 to convert gross energy to digestible energy.

Table 2: Growth performance parameters of African catfish fed different experimental diets

\begin{tabular}{|c|c|c|c|c|c|c|c|c|}
\hline 泀 & 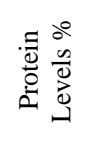 & 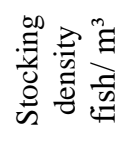 & 急亚 & 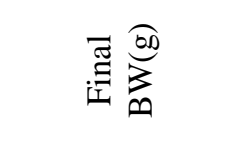 & $\sum_{i}^{0}$ & 导 & 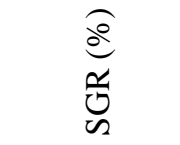 & $\tilde{a} \frac{0}{0}$ \\
\hline 1 & \multirow{3}{*}{25} & 30 & $50.0 \pm 2.58$ & $214.30 \pm 10.12^{\mathrm{c}}$ & $164.30 \pm 8.24^{\mathrm{c}}$ & $1.83 \pm 0.42^{\mathrm{c}}$ & $1.62 \pm 0.32^{\mathrm{ab}}$ & $99.80 \pm 5.54$ \\
\hline 2 & & 20 & $50.0 \pm 2.44$ & $227.00 \pm 11.24^{\mathrm{c}}$ & $177.00 \pm 9.54^{\mathrm{c}}$ & $1.97 \pm 0.51^{\mathrm{c}}$ & $1.40 \pm 0.38^{\mathrm{c}}$ & $100.0 \pm 0.00$ \\
\hline 3 & & 10 & $50.0 \pm 2.64$ & $256.30 \pm 12.54^{\mathrm{ab}}$ & $206.30 \pm 10.25^{\mathrm{ab}}$ & $2.29 \pm 0.61^{\mathrm{ab}}$ & $1.57 \pm 0.30^{\mathrm{b}}$ & $100.0 \pm 0.00$ \\
\hline 4 & \multirow{3}{*}{30} & 30 & $50.0 \pm 2.87$ & $233.60 \pm 11.87^{\mathrm{bc}}$ & $183.60 \pm 8.98^{\mathrm{bc}}$ & $2.04 \pm 0.54^{\mathrm{bc}}$ & $1.45 \pm 0.24^{\mathrm{c}}$ & $99.90 \pm 4.87$ \\
\hline 5 & & 20 & $50.0 \pm 2.67$ & $247.00 \pm 12.54^{\mathrm{b}}$ & $197.00 \pm 9.68^{b}$ & $2.19 \pm 0.55^{\mathrm{b}}$ & $1.52 \pm 0.29^{\mathrm{bc}}$ & $100.0 \pm 0.00$ \\
\hline 6 & & 10 & $50.0 \pm 2.64$ & $284.00 \pm 14.32^{\mathrm{a}}$ & $234.00 \pm 11.23^{\mathrm{a}}$ & $2.60 \pm 0.63^{\mathrm{a}}$ & $1.71 \pm 0.41^{\mathrm{a}}$ & $100.0 \pm 0.00$ \\
\hline
\end{tabular}

A,b and c mean the column bearing different letters differ significantly at 0.05 level 
Table 3: Water parameters during the experimental period

\begin{tabular}{|c|c|c|c|c|c|c|c|}
\hline Parameters & $\mathrm{T} 1$ & $\mathrm{~T} 2$ & T3 & $\mathrm{T} 4$ & $\mathrm{~T} 5$ & T6 & Standard no. \\
\hline Temperature & $27.5^{\circ}$ & $27.8^{\circ}$ & $28.1^{\circ}$ & $28.3^{\circ}$ & $27.7^{\circ}$ & $28.5^{\circ}$ & $20: 32$ \\
\hline $\mathrm{Ph}$ & 8.2 & 8.4 & 8.3 & 8.5 & 8.2 & 8.3 & $6.5-8$ \\
\hline Dissolved $\mathrm{O}_{2}$ & 6 & 6 & 6 & 6 & 6 & 6 & $>4$ \\
\hline $\mathrm{NO}_{2}$ & Nil & Nil & Nil & Nil & Nil & Nil & $<0.2$ \\
\hline $\mathrm{NH}_{3}(\mathrm{mg} / \mathrm{l})$ & $0.6: 0.9$ & $0.6: 0.9$ & $0.6: 0.9$ & $0.6: 0.9$ & $0.6: 0.9$ & $0.6: 0.9$ & $<0.6$ \\
\hline Alkalinity & 320 & 320 & 320 & 320 & 320 & 320 & $<500$ \\
\hline Hardiness & 150 & 150 & 150 & 150 & 150 & 150 & $<500$ \\
\hline Salinity ppm & 4000: 2000 & 4000: 2000 & $2000: 4000$ & 4000: 2000 & $2000: 4000$ & 4000: 2000 & $0-5000$ \\
\hline
\end{tabular}

Table 4: Average feed intake, feed conversion ratio, protein efficiency ratio (\%), feed efficiency and protein productive value of African catfish fed different experimental diets

\begin{tabular}{|c|c|c|c|c|c|c|c|}
\hline 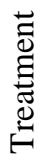 & 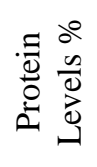 & 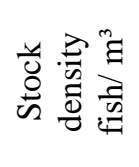 & 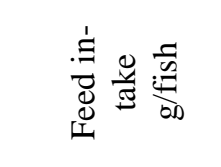 & 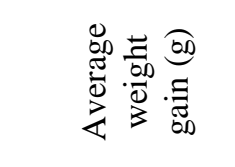 & 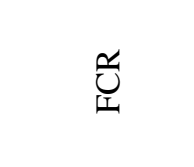 & $\frac{\underline{r}}{\underline{\Delta}}$ & $\vec{a}$ \\
\hline 1 & \multirow{3}{*}{25} & 30 & $230.56 \pm 11.24$ & $164.30 \pm 8.24^{\mathrm{c}}$ & $1.40 \pm 0.24^{\mathrm{c}}$ & $2.80 \pm 0.35^{\mathrm{c}}$ & $19.09 \pm 2.15^{\mathrm{b}}$ \\
\hline 2 & & 20 & $231.25 \pm 11.35$ & $177.00 \pm 9.54^{\mathrm{c}}$ & $1.31 \pm 0.18^{\mathrm{bc}}$ & $3.01 \pm 0.57^{\mathrm{b}}$ & $20.56 \pm 2.22^{b}$ \\
\hline 3 & & 10 & $233.33 \pm 11.57$ & $206.30 \pm 10.25^{\mathrm{ab}}$ & $1.13 \pm 0.11^{\mathrm{a}}$ & $3.47 \pm 0.64^{\mathrm{a}}$ & $23.79 \pm 2.11^{\mathrm{a}}$ \\
\hline 4 & \multirow{3}{*}{30} & 30 & $230.56 \pm 10.98$ & $183.60 \pm 8.98^{\mathrm{bc}}$ & $1.26 \pm 0.17^{\mathrm{b}}$ & $2.62 \pm 0.38$ & $17.96 \pm 1.98^{c}$ \\
\hline 5 & & 20 & $231.25 \pm 10.89$ & $197.00 \pm 9.68^{b}$ & $1.17 \pm 0.12^{\mathrm{ab}}$ & $2.80 \pm 0.37^{\mathrm{c}}$ & $19.20 \pm 2.08^{b}$ \\
\hline 6 & & 10 & $233.33 \pm 11.47$ & $234.0 \pm 11.23^{\mathrm{a}}$ & $1.00 \pm 0.09^{\mathrm{a}}$ & $3.30 \pm 0.55^{\mathrm{ab}}$ & $22.56 \pm 2.34^{\mathrm{a}}$ \\
\hline
\end{tabular}

A,b and $\mathrm{c}$ mean the column bearing different letters differ significantly at 0.05 level

Table 5: Body composition of African catfish as affected by the experimental diets (\% on dry matter basis)

\begin{tabular}{|c|c|c|c|c|c|}
\hline \multirow{2}{*}{$\begin{array}{c}\text { Treat. } \\
\text { No }\end{array}$} & \multicolumn{5}{|c|}{$\%$ On Dry matter basis } \\
\hline & $\mathrm{DM}$ & $\mathrm{CP}$ & $\mathrm{EE}$ & Ash & $\mathrm{GE}^{* *}(\mathrm{Kcal} / 100 \mathrm{~g})$ \\
\hline \multicolumn{6}{|c|}{ At the start of the experiment } \\
\hline & $25.00 \pm 1.15$ & $62.80 \pm 4.56$ & $14.10 \pm 1.22$ & $20.95 \pm 0.38$ & $497.14 \pm 11.5$ \\
\hline \multicolumn{6}{|c|}{ At the end of the experiment } \\
\hline T1 & $28.78 \pm 1.58$ & $66.92 \pm 5.36$ & $17.08 \pm 1.54$ & $13.90 \pm 0.15$ & $548.34 \pm 15.24$ \\
\hline $\mathrm{T} 2$ & $29.12 \pm 1.64$ & $67.13 \pm 4.87$ & $17.02 \pm 1.36$ & $13.91 \pm 0.21$ & $548.31 \pm 14.28$ \\
\hline $\mathrm{T} 3$ & $29.11 \pm 1.52$ & $67.36 \pm 5.24$ & $16.94 \pm 1.54$ & $13.74 \pm 0.32$ & $548.94 \pm 13.47$ \\
\hline $\mathrm{T} 4$ & $29.09 \pm 1.66$ & $67.33 \pm 5.11$ & $16.77 \pm 1.74$ & $13.94 \pm 0.22$ & $547.16 \pm 13.65$ \\
\hline T5 & $29.19 \pm 1.87$ & $67.36+5.22$ & $16.77 \pm 1.64$ & $13.87 \pm 0.19$ & $547.50 \pm 13.78$ \\
\hline T6 & $29.21 \pm 1.75$ & $67.39 \pm 5.47$ & $16.79 \pm 1.77$ & $13.78 \pm 0.24$ & $548.03 \pm 14.55$ \\
\hline
\end{tabular}

A,b and c mean the column bearing different letters differ significantly at 0.05 level.

**Gross energy was calculated according to NRC (1993) by using factors of 5.65, 9.45 and 4.22 Kcal per 1 gram of protein, lipid and carbohydrate, respectively 
Table 6: Effect of protein levels and stocking denesity on the haematological parameters in catfish fingerlings

Haematological parameters

\begin{tabular}{|c|c|c|c|c|c|c|}
\hline 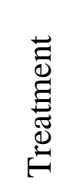 & 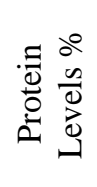 & 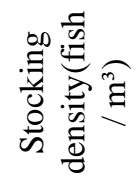 & 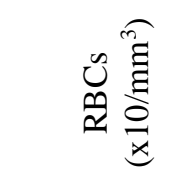 & 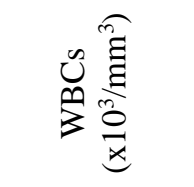 & 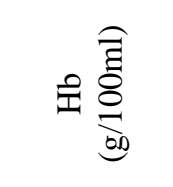 & $\overrightarrow{2}$ \\
\hline T1 & 25 & 30 & $2.48 \pm 0.05^{d}$ & $75.86 \pm 1.12^{b}$ & $7.62 \pm 0.41^{c}$ & $21.00 \pm 0.5^{\mathrm{a}}$ \\
\hline $\mathbf{T} 2$ & & 20 & $2.58 \pm 0.2^{b}$ & $73.45 \pm 0.81^{d}$ & $7.63 \pm 0.15^{c}$ & $22.50 \pm 0.5^{a}$ \\
\hline T3 & & 10 & $2.68 \pm 0.14^{b}$ & $74.23 \pm 1.3^{c}$ & $7.64 \pm 0.33^{c}$ & $22.00 \pm 0.5^{a}$ \\
\hline T4 & 30 & 30 & $2.63 \pm 0.4^{c}$ & $76.07 \pm 2.1^{b}$ & $7.70 \pm 0.41^{a}$ & $23.50 \pm 1.0^{a}$ \\
\hline T5 & & 20 & $2.72 \pm 0.2^{\mathrm{a}}$ & $72.51 \pm 0.5^{\mathrm{e}}$ & $7.79 \pm 0.5^{\mathrm{ab}}$ & $23.50 \pm 1.0^{a}$ \\
\hline T6 & & 10 & $2.83 \pm 0.08^{a}$ & $67.23 \pm 0.59^{f}$ & $7.82 \pm 0.28^{a}$ & $24.00 \pm 0.19^{a}$ \\
\hline
\end{tabular}

RBCs= Red Blood cells; WBCs $=$ White Blood cells; $\mathrm{Hb}=$ Hemoglobin; PCV = Packed Cell Volume

\section{Conclusion}

Both Stocking density and Protein level in fish diet have a significant effect on growth rate, feed utilization, physiological responses and survival rate Clarias gariepinus fingerlings in concrete tanks. Based on the results of the current study, it could be recommended to use protein level diet of $30 \%$ or more in combination with stocking density of $10 \mathrm{fish} / \mathrm{m}^{3}$ to obtain higher production in a short time.

\section{Conflict of interest}

The authors declare that they have no conflict of interest.

\section{References}

1. Omotoyin BO. Introduction to Fish Farming in Nigeria. Ibadan University Press, Publishing House, University of Ibadan, Ibadan, Nigeria. 2007; 60.

2. Nwipie GN, Erondu ES, Zabbey N. Influence of Stocking Density on Growth and Survival of Post Fry of the African Mud Catfish, Clarias gariepinus. Fish Aquac J 2015; 6(1) DOI: 10.4172/2150-3508.1000116

3. World Bank. Marketing Africa's High-value Foods: Comparative Experiences of an Emergent Private Sector. Steven J. and John M (eds). 1995: 117.

4. Barua G. Gonadal development and fry rearing of Clarias batrachus. 1990.

5. Zonneveld N, Fadholi R. Feed intake and growth of red tilapia at different stocking densities in ponds in Indonesia. Aquaculture 1991; 99: 83-
94.

6. Goda AM, El-Haroun ER, Chowdhury MA. Effect of totally or partially replacing fish meal by alternative protein sources on growth of African catfish, Clarias gariepinus (Burchell. 1822) reared in concrete tanks. Aquac Res 2007; 38: 279-87.

7. Nyina-wamwiza L, Wathelet B, Kestemont P. Potential of local agricultural by-products for the rearing of African catfish Clarias gariepinus in Rwanda: effects on growth, feed utilization and body composition. Aquac Res 2007; 38:206-14.

8. Osman AGM, Wuertz S, Mekkawy IAA, Exner H, Kirschbaum F. Embryo-toxic effects of lead nitrate of the African catfish Clarias gariepinus (Burchell, 1822). J. Ichthyol. 2007; 23: 4858.

9. Abdelhamid AM. Recent Trends in Fish Culture. New Universal Office, Alexandria. $2009^{\mathrm{a}}$.

10. Khan MA, Abidi SF. Dietary arginine requirement of Heteropneustes fossilis fry (Bloch) based on growth, nutrient retention and hematological parameters. Aquac Nut 2011; 17:418-28.

11. Richter CJJ, Eding EH, Verreth JAJ, Fleuren WLJ. African catfish (Clarias gariepinus). In: N.R. Bromage \& R.J. Roberts (eds). Broodstock Management and Nutrition and Egg and Larval Quality. Blackwell Scientific Publications, Oxford, 1995; pp 42.

12. Dada AA, Wonah C. Production of exotic $C$. gariepinus at varying stocking density in outdoor ponds. J aqua Sci 2003;18(1): 21-4.

13. Chor WK, Lim LS, Shapawi R. Evaluation of feather meal as a dietary protein source for African Catfish fry, Clarias gariepinus. J Fish Aquac Sci 2013; 8:697-705. 
14. Madu CT, Udodike EBC, Ita EO. Food and feeding habits of hatchlings of mudfish Clarias anguillaris (L). Afr J Aquat Sci 1990; 5: 27-31.

15. Ibrahim MSA, Mona HA, Mohammed A. Zooplankton as live food for fry and fingerlings of Nile Tilapia (Oreochromis niloticus) and Catfish Clarias gariepinus in Concrete ponds. Central Laboratory for Aquaculture Research. (CLAR), Abbassa, Sharkia, Egypt. 8th Int Symp Tilapia in Aquac 2008; 757-69.

16. Sirakov I, Invacheva E. Influence of stocking density on the growth performance of rainbow trout and brown trout grown in re- circulatory system. Bulg J Agric Sci 2008; 14(2): 150-4.

17. AOAC. Official methods of Analysis. In: Association of Official Analysis of Chemists, Washington D.C. $15^{\text {th }}$ Ed. 1990

18. APHA (American Public Health Association, American Water Works Association, and Water Pollution Control Federation). Standard Methods for the Examination of Water and Wastewater. 17th edition. APHA. Washington, DC. 1989

19. Annet CS. A model to facilitated optimal aquaculture production by quantitatively relating fish growth to feed and other environmental resources. Ph.D., Thesis, Michigan. State University, U.S.A. 1985.

20. Pouomonge V, Mbonglang M. Effect of feeding rate on the growth of tilapia (O. niloticus) in earthen ponds. Isr J aquac 1993; 45: 147-53.

21. De Silva SS, Anderson TA. Fish Nutrition in Aquaculture, Ed., Champman and Hall, 2-6 Bouday Raw, London SEI8 FIN, UK. 1995.

22. Stoskopf MK. Fish medicine Ed., W.B. Sainders Company, London. 1993.

23. Zinkle JG. Avian hematology.In: Jain NC (Ed. Schalms) Veterinary Hematology, Philadelphia, Paihea and Febiger. 1986; 256-60.

24. Decie SIV, Lewis SM. Practical Haematology. Pp.736. Churchill Livingstone, London. ISBN: 13:978-0-443-06660-3. 10 ${ }^{\text {th }}$ Ed. 2006.

25. SPSS. Statistical package for the social sciences, Revisions 6, spss Inc, Chicago, USA. 1997.

26. Duncan DB. Multiple Ranges and Multiple F- test. Biometerics 1955; 11:1-42.

27. Rahman MA, Mazid MA, Rahman MR, Khan MN, Hossain MA. Effect of stocking density on survival and growth of critically endangered mashseer, Torputitora (Hamilton), in nursery ponds. Aquaculture 2005; 249: 275-84.

28. Suziki N, Kondo M, Günes E, Özongun M, Ohno A. Age and growth of Turbot Psetta maxima in the Black Sea, Turkey. Turk J Fish Aquat Sci
2001;1: 43-53.

29. Phonekhampheng O. On-farm Feed Resources for Catfish (Clarias gariepinus) Production in Laos: Evaluation of Some Local Feed Resources. Dissertation submitted as a partial fulfillment of the requirements for the degree of Doctor of Philosophy, Swedish University of Agricultural Sciences. 2008; Pp 65.

30. Diyaware MY, Modu BM, Yakubu UP. Effect of different dietary protein levels on growth performance and feed utilization of hybrid catfish (Heterobranchus bidorsalis $\times$ Clarias anguillaris) fry in north- east Nigeria. Afr J Biotechnol 2009; 8: 3954-7.

31. Kiriratnikom S, Kiriratnikom A. Growth, feed utilization, survival and body composition of fingerlings of slender walking catfish, Clarias nieuhofii, fed diets containing different protein levels. Songklanakarin J. Sci. Technol 2012; 34 (1):37-43.

32. Ahmad M, Qureshi TA, Singh AB, Manohar S, Kamlesh B, Salman RC. Effect of dietary protein, lipid and carbohydrate contents on the growth, feed efficiency and carcass composition of Cyprinus carpio communis fingerlings. Int J Fish Aquac 2012; 4(3):30-40.

33. Hecht T. A Review of on-farm feed management practices for North African catfish (Clarias gariepinus) in sub-Saharan Africa. In: Hasan M. Rand New M.B(ed.),On-farm Feeding and Feed Management in Aquaculture, FAO Fisheries and Aquaculture Technical Paper No. 583, Rome, Italy, 2013; pp: 463-479, 282-9.

34. Edward A, Ladu BMB, Elihu A. Growth, survival and production economics of Clarias gariepinus fingerlings at different stocking densities in concrete tanks. Afr J Gen Agric 2010; 6(2):5966.

35. Gonçalves De Oliveira EG, Pinheiro AB, de Oliveira VQ, da Silva únior ARM, de Moraes MG, Rocha IRCB, de Sousa RR, Costa FHF. Effects of stocking density on the performance of juvenile pirarucu (Arapaima gigas) in cages. Aquaculture 2012; 370-371:96-101.

36. Jiwyam W, Nithikulworawong N. Stocking density-dependent growth and survival of Asian red-tailed catfish (Hemibagrus wyckioides) fries: early nursing in cages. Int Aquat Res 2014; 6:24550

37. Josiah AS, Mwatete MC, Njiru J. Effects of greenhouse and stocking density on growth and survival of African catfish (Clarias gariepinus 
Burchell 1822) fry reared in high altitude Kenya regions. Int J Sci Res 2014; 3(9):558-63.

38. Abdur Rahim AG, Ferrando S, Gallus L, Abdul Ghaffar A, Hafeez-ur-Rehman M, Waryani B. Effects of varying dietary protein level on growth, nutrient utilization and body composition of juvenile black fin sea bream, Acanthopagrus berda (Forsskal,1775). Pakistan J Zool 2016; 48(4):108997.

39. Barton BA, Morgan JD, Vijayan MM. Physiological and condition-related indicators of environmental stress in fish. In: Biological Indicators of Aquatic Ecosystem Health, Adams S.M. (ed.), American Fisheries Society, Bethesda, M.D, 2002; pp: 111-48.

40. Mohanta KN, Subramanian S, Korikanthimath VS. Effect of dietary protein and lipid levels on growth, nutrient utilization and whole-body composition of blue gourami, Trichogaster trichopterus fingerlings. J Anim Physiol Anim Nut 2013; 97:126-36.

41. Boyd CE. Water Quality in warm water fish ponds. Anburn University, Alabama. 1979; p 359.

42. Abdelhamid AM. Field and Laboratorial Analysis in Animal Production. 1st Edn., Dar Alnashr for Universities, Cairo, Egypt. 1996.

43. Abdelhamid AM. Fundamentals of Fish Production and Culture. New Universal Office, Alexandria. 2009

44. FAO. Fisheries and food security, Documentation issued on the occasion of the world food summit in Rome (1996), Food and Agriculture organization of the United Nations, Rome, Italy, 1996; p: 2.

45. Abdelhakim NF, Baker MN, Soltan MA. Aquatic Environment for Fish Culture. Faber and Faber, Cairo. 2002.

46. Dai W, Wang XM, Guo YJ, Wang Q, Ma $\mathrm{JH}$. Growth performance, hematological and biochemical responses of African catfish (Clarias gariepinus) reared at different stocking densities. Afr J Agric Res 2011; 6(28): 6177-82.
47. Florence ON, Harrison TO. Impact of Stocking Density on the Polyculture of Clarias gariepinus and Oreochromis niloticus. J Agric Sci Technol 2012; 2: 1018-23.

48. Kyoung DK, Kang WK, Bong JL, Maeng HS, Hyon SH, Jin DK. Dietary protein requirement for young far eastern catfish Silurus asotus. Fish Aquat Sci 2014; 17(4):455-9.

49. Suharmili R, Kamarudin MS, Saad CR, InaSalwany MY, Ramezani-Fard E, Mahmud MH. Effects of varying dietary protein level on the growth, feed efficiency and body composition of lemon fin barb hybrid fingerlings. Iran J Fish Sci 2015; 14(2):425-35.

50. Xia S, Sun Z, Feng S, Zhang Z, Rahman MM, Rajkumar M. Effects of dietary protein level on growth and ammonia excretion of Leopard coral grouper, Plectropomus leopardus (Lacepede, 1802). Sains Malaysiana, 2015; 44(4):537-43.

51. Jha P, Barat S. The effect of stocking density on growth, survival rate and number of marketable fish produced of Koi carp, Cyprinus carpio vr. Koi; in concrete tanks. J Appl Aquac 2005; 17: 84-102.

52. Kim KW, Wang XJ, Bai SC. Optimum dietary protein level for maximum growth of juvenile olive flounder, Paralichthys olivaceus (Temminck and Schlegel). Aquac Res 2002; 33: 673-9.

53. Farhat KMA, Khan MA. Growth, feed conversion and nutrient retention efficiency of African catfish, Clarias gariepinus (Burchell) fingerling fed diets with varying levels of protein. J Appl Aquac 2011; 23:304-16.

54. Kpogue D, Gangbazo H, Fiogbe E. A preliminary study on the dietary protein requirement of Parachanna obscura (Günther, 1861) larvae. Turk J Fish Aquat Sci 2013; 13:111-7.

55. Aliyu-Paiko M, Hashim R, Shu-Chien AC. Influence of dietary lipid/protein ratio on survival, growth, body indices and digestive lipase activity in snakehead (Channa striatus, Bloch1793) fry reared in re-circulating water system. Aquac Nut 2010; 16: 466-7. 